\section{Access to highly active antiretroviral therapy for injection drug users: adherence, resistance, and death}

\author{
Acesso de usuários de drogas injetáveis ao \\ tratamento anti-retroviral altamente potente: \\ aderência, resistência e mortalidade
}

David Vlahov 1

David D. Celentano 2

\footnotetext{
1 Center for Urban Epidemiologic Studies, New York Academy of Medicine, New York, U.S.A. 2 Department of Epidemiology, Johns Hopkins Bloomberg School of Public Health, Baltimore, U.S.A.

Correspondence D. Vlahov Center for Urban Epidemiologic Studies, New York Academy of Medicine.

1216 Fifth Avenue, New York, 10029, U.S.A. dvlahov@nyam.org
}

\begin{abstract}
Injection drug users (IDUs) continue to comprise a major risk group for HIV infection throughout the world and represent the focal population for HIV epidemics in Asia and Eastern Europe/Russia. HIV prevention programs have ranged from HIV testing and counseling, education, behavioral and network interventions, drug abuse treatment, bleach disinfection of needles, needle exchange and expanded syringe access, as well as reducing transition to injection and primary substance abuse prevention. With the advent of highly active antiretroviral therapy (HAART) in 1996, dramatic clinical improvements have been seen. In addition, the treatment's impact on reducing HIV viral load (and therefore transmission by all routes) provides a stronger rationale for an expansion of the focus on prevention to emphasize early identification and treatment of HIV infected individuals. However, treatment of IDUs has many challenges including adherence, resistance and relapse to high risk behaviors, all of which impact issues of access and ultimately effectiveness of potent antiretroviral treatment. A major current challenge in addressing the HIV epidemic revolves around an appropriate approach to HIV treatment for IDUs.
\end{abstract}

Highly Active Antiretroviral Therapy; Intravenous Substance Abuse; HIV Infections

\section{Introduction}

\section{Background of drug user related HIV risks}

The association of drug abuse and HIV infection is well appreciated and several mechanisms may underlie this association. Foremost, administration of drugs by injection with multiple reuse of injection equipment, and possibly sharing straws or pipes for inhalation, can transmit fluids that contain HIV 1,2. Also, the psychoactive effect of drugs can impair judgment and reduce impulse control for sexual as well as injection risks and treatment adherence 3 . Finally, the direct pharmacologic action of drugs on immunological susceptibility or up-regulation of HIV has been reported in vitro and in vivo ${ }^{4}$. While data on the impact of continuing drug use on HIV progression has been inconclusive 5 , the role of drugs in HIV acquisition remains an open question and warrants further research 6 .

\section{Scope of the problem}

In 2004, the World Health Organization (WHO) reported that estimates of injection drug user (IDU) prevalence were available for 130 countries and the number of IDUs worldwide is approximately 13.2 million 7 . Over ten million (78\%) live in developing and transitional countries (Eastern Europe and Central Asia, 3.1 mil- 
lion; South and Southeast Asia, 3.3 million; East-Asia and Pacific, 2.3 million) 8 . HIV prevalence among IDUs of over $20 \%$ was reported for at least one site in 25 (of 78 reporting) countries and territories: Belarus, Estonia, Kazakhstan, Russia, Ukraine, Italy, Netherlands, Portugal, Serbia and Montenegro, Spain, Libya, India, Indonesia, Malaysia, Myanmar, Nepal, Thailand, Vietnam, China, Argentina, Brazil, Uruguay, Puerto Rico, USA and Canada. Twenty-six countries reported injection drug use as the primary mode of HIV transmission 7. Comparable data on drugs used by other modes of administration are sparse. The UN Office of Drug Control estimates world wide there are over 200 million illicit drug users; 34 million using amphetamines, 15 million using opiates, 14 million using cocaine, 8 million using ecstasy (http:// www.unodc.org/unodc/en/global_ilicit_drug_ trends.html, accessed on 09/Mar/2005). Alcohol use is considerably higher 9 . Thus, the problem of HIV infection among injection and non-injection drug users is prevalent world-wide.

\section{Approaches to preventing acquisition of HIV infection in drug users}

The most widely advocated approach for prevention of HIV transmission among drug users has been drug abuse treatment 10 . Early clinical trials have shown that methadone treatment reduces drug use although relapse is frequent 11. Limited observational data suggest lower HIV rates in IDUs during drug abuse treatment 12 , but it is difficult to determine whether the lower rates reflect selection issues. No trial has been reported to show whether treatment (rather than selection) reduces HIV incidence. To date, only the U.S. National Institutes of Health (NIH) funded HIV Prevention Trial Network (HPTN) protocol (058), testing a newly approved medication, buprenorpine, will address this question for opiate users. While opiate treatments have received considerable attention, HIV infection related to stimulant abuse (cocaine, methamphetamines) whether injected, ingested or inhaled, has received growing attention especially from recent reports relating a link between stimulant use and the resurgence of risky behavior (e.g., barebacking) and HIV infection in gay men in the US, South America and Asia 13,14,15,16,17,19,19,20,21,22,23. Behavioral and pharmaceutical treatments for stimulant abuse are evolving and early data suggest promise for reducing sexual risk 24,25; formal evaluation of these treatments for reducing HIV incidence is urgently needed. Mar- ijuana and alcohol abuse are more widespread and of concern globally including Africa 26,27,28, but have received considerably less attention by the HIV prevention community.

Other approaches for HIV prevention are needed for those who can not or will not stop injection drug use. While results from multiple trials of counseling/testing and individual level cognitive behavioral interventions in IDUs have been disappointing 29,30, interventions using a social learning theory based approach 31 including peer networks and, more broadly, indigenous opinion leaders have shown promise in reducing risk behavior $32,33,34,35$. Currently, The HPTN protocol 037 is in the field and provides a formal test of peer network intervention in two countries, using HIV seroconversion as the primary outcome. While field data on disinfection of injection equipment has been disappointing $36,37,38,39,40$, improved access to sterile injection equipment has been studied extensively and shown to reduce HIV incidence 41.

While drug abuse treatment, network and outreach approaches represent the current state of the science, their influence is dependent upon local norms and policies. Researchers have been moving beyond individual and peer network interventions, which are essentially individual or dyadic, toward structural and multi-level interventions 42,43,44,45,46,47, $48,49,50,51,52,53,54,55$. Recent data from China for a primary substance abuse prevention effort showed promising results although HIV outcomes were not considered 56. For IDUs, structural interventions involve policy changes such as increasing availability of substance abuse treatment and access to sterile syringes, e.g., removing requirements that penalize prescription and possession of sterile syringes; nonrandomized designs have shown reductions in high risk behaviors 57,58 , although the impact on HIV acquisition remains unknown. Multilevel interventions include education not only of IDUs through street outreach, but also of providers (e.g., pharmacists) and the community to support HIV prevention efforts; nonrandomized designs have shown reductions in high risk behaviors $47,51,54$. A coordinated approach with multiple components of intervention at varying levels are urgently needed as new HIV epidemics among IDUs often are characterized by rapid and even explosive spread in many countries, including China, Russia, Ukraine, Brazil, India and Vietnam, where HIV prevalence has increased from $<10 \%$ to $>40 \%$ in a one-year time period 1 .

Admittedly, evaluation of multi-component programs directed at multiple levels (consumer, 
provider, community) is difficult. For example, traditional prospective designs for cohort formation and follow-up have been difficult to field for drug users. However, a convergence of methodological advances in serial cross-sectional design using rapid assessments 59, randomization by geographic units, respondent driven sampling (http://www.respondentdrivensampling.org, accessed on 09/Mar/2005) and detuned assays for HIV 60 (using cross-sectional surveys with state-of-the-art laboratory assays that can determine the prevalence of recent - past six months - infections among those who are screened HIV positive) have provided a feasible alternative to community trials. With limited data suggesting effectiveness for each prevention component, a non-intervention control group is ethically suspect; a more appropriate design that conforms to the reality of staggered introduction across geographical units is to compare early versus delayed intervention sites. Alternatively, interventions for the control group that focus on other potentially helpful behavior changes are being applied in the field, often in response to suggestions from community advisory boards or other advocacy groups. The underlying approach of multi-component interventions (e.g., drug abuse treatment, needle exchange, outreach, etc.) performed at multiple levels (outreach to drug users, to pharmacists who can dispense syringes, etc.) is not merely to provide wider coverage of as many program parts as possible, but to provide the conditions for changing norms at multiple levels to reinforce the importance of sustained HIV risk reduction.

\section{Risks with modes of transmission} other than drug administration

Factors other than multiple reuse of injection equipment are important in controlling HIV among IDUs. As noted above, sexual risks from drug use are vast. A common but faulty image of drug users as a socially marginalized community undermines the fact that drug users can play a critical role in the spread of HIV into the broader population through heterosexual, homosexual and perinatal transmission. Recent reports show that IDUs who reduced injection risk had not similarly reduced their sexual risks $61,62,63$. Stimulant use in gay men, which is reported with increasing frequency, is associated with elevated HIV risk 13,14,15,16,17,18, $19,20,21,22,23$. Overlapping drug and sexual risks are reported for especially vulnerable youth around the world, such as children living in the streets 64 . To date, formal evaluation with ran- domized controlled trials of programs for reducing substance use related HIV risks (direct and indirect, as with effects on sexual risks) has lagged behind trials for other areas of HIV prevention (e.g., STDs control, early HIV treatment, reducing perinatal transmission); conversely, these other interventions have not fully considered or incorporated implications of substance abuse, including alcohol. Sufficient data are now available to develop and scale up trials relating to reducing a broader array of substance use related HIV risks.

\section{Primary and secondary prevention of HIV with antiretroviral treatment for drug users}

Highly active antiretroviral therapy (HAART) significantly improves the prognosis of HIV-infected persons, by reducing HIV viral load, increasing CD4+ cell levels, delaying progression to AIDS and reducing mortality 65,66,67,68,69,70,71. A secondary consideration is that the reduced HIV viral load may be important for reducing transmission, and as such, the availability of HAART may be an important addition to the arsenal of HIV prevention tools described thus far. However, there are a number of considerations about the use of HAART in populations of drug users. The unresolved issues include questions about whether the degree of effectiveness of HAART is affected by potential differences between the natural history of HIV infection in drug users and other populations (due to the effects of the illicit drugs themselves on natural history) and concerns about access to HIV treatment and adherence to HAART regimens. In addition, questions of treatment effectiveness for IDUs lead to concerns about whether clinical improvement may lead to behavioral relapse, which in turn may lead to reduced regime adherence, the development of antiretroviral therapy resistance, and, ultimately, its transmission to others through risky sexual and/or drug use behaviors.

\section{Natural history of HIV in drug users}

Providing HIV treatment to drug users first must acknowledge that guidelines for treatment have been developed primarily from cohort studies that have not included drug users or considered drug use within the population being studied. An early question therefore is whether the natural history of HIV infection is influenced by use of illicit drugs. An analysis comparing HIV seroconverters in the ALIVE 
Study (IDUs) to seroconverters in the SHARE study (men who have sex with men or MSM) in Baltimore, USA, found that there were larger changes in CD4+ and CD8+ among MSM following seroconversion compared to IDU 72 . However, these modest and non-significant differences were limited to the first two years after seroconversion, after which point CD4+ decline rates converged. While this report was limited to observations up to four years post seroconversion, a study by Pezzotti et al. 73 examined CD4+ cell decline among seroconverters with longer follow-up and found a continued pattern of no difference by active or former drug use or between exposure risk groups (including IDUs, MSM and persons infected by heterosexual contact). While the ALIVE study was complicated by the fact that over two-thirds of drug users were poly-substances users, the Italian cohort was limited predominantly to heroin only users, thus reducing the concern that differences observed in laboratory studies compared to those observed in cohort studies were a function polydrug use, which may have offset the effects of individual drug use on CD4+ decline. In an early analysis (before the advent of HAART) that compared rate of progression to AIDS between injection drug users from Baltimore (mostly African-American) and Italy (mostly white) as well as comparison to Italian MSM and those infected through heterosexual contact, no differences were noted after accounting for age 74 , suggesting that natural history of HIV was unlikely to be affected in a major way by use of illicit drugs. The implications were that concerns over a possible difference in HIV progression due to illicit drug use would not be a major consideration when developing clinical guidelines for HIV treatment. Data on effectiveness of HAART should not therefore differ between risk groups, and treatment should not be withheld from IDUs seeking care because of concerns with the effect of continuing opioid or other drug use on HAART.

\section{Effectiveness of HAART in HIV infected injection drug users}

Epidemiologic studies of the effects of drug use on the course of HIV progression among those who have initiated HAART have shown mixed results $75,76,77,78,79,80$. Findings from the Swiss HIV Cohort Study 75 and the EuroSIDA study 76 provide evidence indicating no significant difference in HIV progression among injection drug users compared to MSM and heterosexual HIV seropositive individuals receiving HAART.
Two reports were published from the ALIVE study, showing high effectiveness of HAART among IDUs with late stage HIV infection with no differences by type, frequency or route of administration 77,78 . However, Lucas et al. 79 reported reduced HAART induced viral load suppression among active IDUs compared to former and non-users $\left(0.8 \log _{10}\right.$ copies/ml versus $1.6 \log _{10}$ copies $/ \mathrm{ml}$ in former users and 1.7 $\log _{10}$ copies/ml in non-users). The authors found these findings were significantly associated with lack of utilization and adherence to HAART among active injection drug users compared to former and non-users ( $34 \%$ vs. $17 \%$ in former users and $24 \%$ in nonusers) 77 . In addition, while Johns Hopkins HIV Clinic investigators Poundstone et al. 80 noted substantial reductions in time to AIDS and death during the HAART era, they found that these gains did not apply equally to IDU. In fact, there was reduced disease-free survival time among IDU compared to non-IDU in the HAART era compared to the period before the advent of HAART 80 . These findings raise the question of whether higher mortality in drug users is due to access 81 and adherence 82 rather than effects of the drug use per se.

\section{Access to HIV therapy has been an issue for injection drug users}

One of the observations from surveillance and cohort data that compares pre- and HAART era HIV care without discriminating who receives treatment is that outcomes are generally worse for IDUs. A principal inference drawn from these observations is that IDUs appear to benefit less because they have less access to HAART. Several studies have examined this issue. Within a year after the introduction of HAART, two cross-sectional studies of HAART use among IDUs were reported. In Vancouver, Canada, where antiretroviral therapy (ART) is offered free to all HIV-infected persons who meet International AIDS Society-USA panel (IAS-USA) guidelines 83 , only $40 \%$ of eligible IDUs received any ART, and $27 \%$ received HAART 84 . Younger individuals, females, those not currently enrolled in drug treatment, and those with inexperienced physicians were less likely to be receiving HAART. In Baltimore, during the same interval, the ALIVE study showed that $14 \%$ of treatment-eligible IDUs reported HAART use between July 1996 and June 1997; $49 \%$ reported no treatment 85 . Factors associated with reporting no ART use included active drug use, sub-optimal HIV health care, not receiving drug treatment and recent incarcera- 
tion. In a subsequent analysis 81 , by June 30 , 1999, 58.5\% of participants initiated HAART, most of whom switched from mono- or dual combination therapy (which were no longer recommended) to a HAART regimen. However, nearly one-third of treatment-eligible IDUs never received antiretroviral therapy. Cox proportional hazards regression showed that initiating HAART was independently associated with not injecting drugs, methadone treatment among men, having health insurance and a regular source of care, lower CD4+ cell count and a history of antiretroviral therapy.

In contrast, use of HAART was quickly adopted in several other populations. For example, in a random sample of HIV-infected individuals in the HIV Cost and Services Utilization Study (HCSUS), $85 \%$ of participants eligible for therapy (CD4+ cell count less than $0.50 \times 109 / \mathrm{L}$ ) reported receiving a PI or non-nucleoside reverse transcriptase inhibitor (NNRTI) treatment by January 31, 1998 86. In this national study, inadequate HIV care was more common among Blacks and Latinos, the uninsured and Medicaid-insured, women and risk groups other than men who had sex with men, even after adjusting for CD4+ cell counts. These data indicate that use of HAART may be less common in those with poor access to health care. Data from the HCSUS represents individuals receiving ongoing care; the sampling strategy used thus under-represents those with access barriers to care 87 . While $20 \%$ of all HCSUS participants were uninsured and $48 \%$ covered by Medicaid, among IDUs these percentages were $15 \%$ and $71 \%$, respectively 87 . In the ALIVE cohort 81 , a larger percentage $(33 \%)$ of IDUs are uninsured, and fewer (54\%) are covered by Medicaid (which generally does not cover medical care for indigent men), underscoring the strong association between health care access and the initiation of effective HIV treatment. Unlike the national data, however, our participants who reported Medicaid insurance were as likely to receive HAART as those who were privately insured. The level of HAART use was substantially lower among our cohort of drug users than the HCSUS drug users.

What is likely to account for lower utilization of HAART among IDUs? Poor utilization of health care among IDUs can be partially explained by the fact that HIV-infected IDUs seek medical attention significantly later in the course of disease, often first presenting to medical care at the time of an AIDS-defining opportunistic infection $88,89,90,91,92$. Once access to care has been addressed, non-HAART use may reflect provider caution in prescribing
HAART. Physician experience with HIV care has also been shown to be associated with IDUs receiving optimal therapy 84 . Studies have shown improved outcomes among HIV-infected patients treated by experienced physicians 93,94,95. Likewise, less experienced providers may continue patients on non-HAART regimens until the patient demonstrates adherence with their medications and clinic visits and substance abuse is under control. Some providers may believe that if IDUs are less likely to attain undetectable viral loads than nonIDUs because of poorer adherence 96, there could be potential transmission of multi-drug resistant HIV 97,98. To ensure long-term success of antiretroviral treatment in patients who can wait to initiate HAART, experienced providers often recommend delaying therapy, until adherence-related issues are addressed 12,25,99,100. Such issues, which include drug and alcohol use, active mental illness, including depression, and homelessness, require referrals to substance abuse treatment, psychiatrists, and social workers. Other factors that may impact adherence to antiretroviral therapy include poor knowledge about HIV infection and treatment and the lack of belief in the efficacy of antiretroviral therapy, which require continual counseling by providers.

In terms of addressing the use of HAART for drug users, integrating ART regimens and drug abuse treatment may offer one avenue for the effective management of these two related medical problems. Current treatment guidelines call for addressing issues of substance abuse as an integral component of HIV management. Participants who reported being on methadone maintenance may be viewed by their providers as being stable and more likely to be adherent to HAART regimens, although some data suggest that this may not be the case for women 81 . It is also possible that methadone treatment may encourage health-seeking behaviors, including ART utilization, among drug users who had previously not sought care. As providers become more experienced in the HIV treatment of drug users, there appears to be increased willingness to prescribe more complex and aggressive therapies for this population. Although several factors are shown to be associated with initiating HAART, ultimately, the decision to start therapy needs to be individualized for each patient.

\section{Adherence}

Adherence to antiretroviral regimens is critical for HIV treatment success 101,102 with adher- 
ence levels of $90 \%$ or more commonly cited as essential for maximal virologic suppression and immunologic protection 103 and in preventing the development of drug resistant viruses 104. This level of adherence is higher than that required for acceptable treatment of other chronic diseases 105. This level of adherence is also difficult to attain given that average adherence rates of $70-75 \%$ are found in primary care settings 103,106 .

As noted above, studies have shown that IDUs are less likely to receive HAART compared to non-drug users $84,85,86$. This underutilization of HAART has been attributed to provider concern about injection drug users' potential for non-adherence due to their unstable lifestyle and other psychosocial problems. Most studies have found injection drug users to be less adherent to combination therapies 107,108,109, but some reports involving small numbers of injection drug users have found the opposite 103,110.

In a recent study from the ALIVE Study 111, $76 \%$ of 366 participants reported $90 \%$ or more adherence to their ART in the prior 3 days. Almost half were on a HAART regimen, of which $64 \%$ were adherent compared to just $36 \%$ among those on non-HAART regimens. This study uses multivariate analyses to show that better adherence was significantly and independently associated with the lack of daily injection drug use, absence of medication-related side effects, use of a medication reminder, and recent participation in a methadone maintenance program.

A major factor in lack of adherence to HIV regimens among substance users is active drug use. Two studies reported a strong relationship between non-adherence and suboptimal virologic and immunologic responses to HIV therapy when the treated individual was an active drug user 109,112. While the association of active injection drug use and non-adherence is consistent across most studies 106,109,112, the finding of no similar significant association among those who occasionally injected suggests that in this case some were adherent and others were not.

The role of drug abuse treatment in adherence has been well established. Early studies that found significantly more adherence among those who attended a methadone program than those who did not attend 113,114. Earlier reports also showed that individuals who attend methadone maintenance treatment programs exhibit a desire for drug addiction recovery and that those who attend such programs are more likely to practice positive health be- haviors 115,116,117,118. Getting injection drug users into drug treatment programs and consistent participation in these programs is essential to reduce their risk behaviors.

With respect to factors associated with ART adherence, important considerations are positive attitude about treatment 119 and medication reminders 106,108,120,121. Forgetfulness is a common reason for missing or skipping a dose, and is a frequently cited reason for lack of adherence across HIV infected populations 106, $107,108,121,122,123$. Assistance with adherence and addressing ongoing illicit drug use may enable occasional users to be more adherent to their antiretrovirals.

\section{Impact of HAART on sexual risk relapse}

Before starting HAART, risk behavior among HIV seropositive people might have been dampened due to concerns about not transmitting to others or due to lack of energy to engage in sexual (including risky) behaviors. With the advent of HAART, there is a concern that persons receiving HAART could relapse to high risk behaviors because learning that they have "undetectable viral load" may lead them to believe they are no longer infectious or simply because feeling better and more invigorated may stimulate interest in sex. However, undetectable viral load does not mean absence of virus, and a relapse could result in possible transmission.

The concern about relapse to high risk behaviors has been examined in a variety of populations. Recent reports indicate increases in high-risk sexual behaviors, anal/rectal gonorrhea, and HIV seroincidence among gay and bi-sexual populations in the HAART era 124,125. Other studies have reported decreased concerns about HIV infection and diminished caution with sexual and drug-use behaviors associated with new HIV therapies 126,127,128,129, 130,131. A recent study found HAART use among gay men to be significantly associated with subsequent increased high-risk sexual behaviors 132. Few studies, however, have reported on reported risk behaviors among IDUs after initiating HAART. A study of HIV-infected French IDUs showed a significant association between HAART use and decreased sexual risk 133. However, another study, among IDUs in Baltimore, reported increased sexual activity, including unprotected sex, among HAART users in the 6month period after HAART initiation, compared to declines in these activities among those who did not initiate HAART 134. HAART initiation, however, was not associated with resumption of drug injection or needle sharing. 
The Baltimore study also considered whether this increase in risky behavior might have been due to "feeling better" or to belief in reduced transmissibility. The data showed no significant difference in the probability of engaging in sex or unprotected sex after HAART when comparing those whose HIV-associated symptoms decreased after HAART to those whose did not 135 . This may suggest that engaging in any sex and unprotected sex may not be a result of improved clinical health or functional status. However, the perception that sexual transmission of HIV is less likely because of HAART and consequent undetectable viral loads was an important factor associated with unprotected sex among HIV-seropositive individuals in the Baltimore study 136 . This supports current concerns raised by the public health community that high-risk populations have become complacent about behaviors that reduce the risk of transmission of HIV and other blood-borne pathogens. This study also supports results obtained in studies of gay/bisexual populations 131, which have experienced a more significant impact of HIV treatments due to greater awareness and higher utilization of HAART. More recently, a meta-analysis examined this question across studies and concluded that relapse to risky behaviors was not a widespread problem 137 .

\section{Drug resistance transmission risk}

The dual issues of HAART effectiveness with poor adherence and possible relapse to high risk sex raises not just the issue of transmitting HIV, but also of transmission of drug resistant HIV to needle sharing or sexual partners, which can limit treatment options in those who become infected with these strains 138 . A recent case in New York City of drug resistant HIV infection and rapid progression to AIDS in a gay man who used methamphetamine drew considerable attention 139. How often this occurs is difficult to assess, but several studies have measured the prevalence of genotypic and/or phenotypic resistance among recent HIV serconverters (who by definition should not have been previously exposed to HAART) 138,140,141, $142,143,144,145,146,147,148,149$. The strongest evidence for transmission of drug-resistant HIV comes from studies showing that up to onequarter $(27 \%)$ of HIV seroconverters have drug resistance mutations 141,142,143,144,145,146, 147,148. For someone to become infected with drug-resistant HIV, that individual must engage in high-risk behavior with a partner who has drug resistance and a viral load that is high enough to allow for HIV transmission. In a study of IDUs in Baltimore 150, among HIV-infected IDUs who engaged in high-risk behavior and had an elevated viral load, $13 \%$ had clinically significant resistance, placing their partners at risk for acquiring a drug-resistant HIV strain. The extent to which this is or will become a problem needs to receive attention not only in targeted surveillance but also through HIV prevention messages.

\section{Conclusion}

The use of HAART for HIV infected illicit drug users remains a complex medical, social and legal issue. Issues of adherence and relapse to risky sexual behavior and development of transmittable resistance to medications all need to be simultaneously addressed. However, reduced access to medication can not be an a priori condition, for once barriers to access are resolved through various means, treatment should be considered. Although some studies have shown effectiveness of HAART in drug users was worse than others patients 79,80 , not all studies report differences between risk groups 76 and definitions of HAART have varied. In a recent report, dramatic improvement in survival was identified in IDUs in pre- vs. post-1996 analyses (85\% reduction in risk) and to a lesser extent in the data restricted to the HAART era that compared treated vs. untreated (50\% reduction in risk) 71 . Some literature suggests that the discrepancy between HAART clinical trials showing $90 \%$ improvement 65 and clinical studies that show $50-70 \%$ improvement was likely due to problems with adherence. Such a conclusion has obvious implications for recommendations for treatment. Epidemiologic studies that showed improvement based on pre- vs. HAART era comparisons in fact might be due to confounding or biasing factors such as survival or frailty biases (rather than perhaps a true improvement due to the medical regimen). However, a recent analysis of putative bias and confounding factors 71 noted that the difference in results noted above was related not only to a dramatic improvement (from pre- to HAART era) among those who received HAART but also among those who had not received HAART after 1996. Further analyses suggested that the differences were more likely to be due to treatment selection (who gets treated and what medications are prescribed), and that effectiveness was not affected by type, frequency or duration of illicit drug use or drug abuse treatment. The implications are that treatment 
can be effective in persons who have used illicit drugs.

While there is significant reluctance among medical care providers to begin HAART therapy with active drug users, the evidence base supporting this decision is quite limited. In our review of the existing literature, the data are not terribly clear on the benefit/risk ratio of commencing HAART therapy earlier rather than suspending initiation until the substance abuse problem in dealt with through replace-

Resumo

Os usuários de drogas injetáveis (UDI) ainda representam um importante grupo de risco para a infecção pelo HIV no mundo em geral, além de constituir o grupo central das epidemias de HIV na Ásia e no Leste Europeu e Rússia. Os programas de prevenção do HIV variam, desde a testagem sorológica e aconselhamento, educação, intervenções comportamentais e em redes, tratamento da dependência química, desinfecção de agulhas com água sanitária, troca de agulhas e ampliação do acesso a seringas, além da redução da transição ao uso injetável e a prevenção primária da dependência química. Com o advento da terapia antiretroviral altamente potente (HAART), em 1996, houve uma melhora clínica dramática. Além disso, o impacto do tratamento sobre a redução da carga viral de HIV (e, portanto, da transmissão do vírus por todas as vias) fornece uma forte justificativa para a ampliação do escopo da prevenção, no sentido de enfatizar a identificação e tratamento precoce de indivíduos infectados. Entretanto, o tratamento dos UDI apresenta inúmeros desafios, inclusive em relação à aderência, resistência e recaída para comportamentos de alto risco, todas as quais têm impacto sobre questões de acesso e, na última análise, da eficácia da HAART. Um importante desafio para o enfrentamento atual da epidemia do HIV gira em torno da busca de uma abordagem apropriada para o tratamento do HIVIAIDS em UDIs.

Terapia Anti-retroviral de Alta Atividade; Uso Indevido de Substâncias Parenterais; Infecções por HIV ment therapy. The few reports with empirical data on substance use and HIV therapy effectiveness in general do not show any additional risk and treatment appears to have excellent impact on both viral load and CD4+ cell count gains. Overcoming residual stigma and discrimination towards drug users by the medical community is essential for optimal treatment to occur. Data to date suggest that drug use is not an automatic exclusion criterion for prescribing HAART.

\section{Contributors}

D. Vlahov \& D. D. Celentano both identified and abstracted the literature, contributed writing sections for the first draft, and both completed writing, review and approval of final draft. As this was a literature review, no ethics review was undertaken. The authors have no conflict of interest.

\section{Acknowledgments}

Supported in part by the National Institute on Drug Abuse (DA 04334). 


\section{References}

1. Stimson G, Des Jarlais DC, Ball A. Drug injecting and HIV infection: global dimensions and local responses. London: World Health Organization/ UCL Press Limited; 1998.

2. Tortu S, McMahon JM, Pouget ER, Hamid R. Sharing of noninjection drug-use implements as a risk factor for hepatitis C. Subst Use Misuse 2004; 39:211-24.

3. Vik PW, Cellucci T, Jarchow A, Hedt J. Cognitive impairment in substance abuse. Psychiatr Clin North Am 2004; 27:97-109.

4. Peterson PK, Gekker G, Schut R, Hu S, Balfour Jr. $\mathrm{HH}$, Chao CC. Enhancement of HIV-1 replication by opiates and cocaine: the cytokine connection. Adv Exp Med Biol 1993; 335:181-8.

5. Pezzotti P, Galai N, Vlahov D, Rezza G, Lyles CM, Astemborski J. Direct comparison of time to AIDS and infectious disease death between HIV seroconverter injection drug users in Italy and the United States: results from the ALIVE and ISS studies. AIDS Link to Intravenous Experiences. Italian Seroconversion Study. J Acquir Immune Defic Syndr Hum Retrovirol 1999; 20:275-82.

6. Pellegrino T, Bayer BM. In vivo effects of cocaine on immune cell function. J Neuroimmunol 1998; 83:139-47.

7. Aceijas C, Stimson GV, Hickman M, Rhodes T; United Nations Reference Group on HIV/AIDS Prevention and Care among IDU in Developing and Transitional Countries. Global overview of injecting drug use and HIV infection among injecting drug users. AIDS 2004; 18:2295-303.

8. Williams PG, Ansell SM, Milne FJ. Illicit intravenous drug use in Johannesburg - medical complications and prevalence of HIV infection. S Afr Med J 1997; 87:889-91.

9. Room R, Babor T, Rehm J. Alcohol and public health. Lancet 2005; 365:519-30.

10. Metzger DS, Navaline H. HIV prevention among injection drug users: the need for integrated models. J Urban Health 2003; 80 (4 Suppl 3):iii59-66.

11. Sullivan LE, Metzger DS, Fudala PJ, Fiellin DA. Decreasing international HIV transmission: the role of expanding access to opioid agonist therapies for injection drug users. Addiction 2005; 100:150-8.

12. Metzger DS, Woody GE, McLellan AT, O’Brien CP, Druley P, Navaline H, et al. Human immunodeficiency virus seroconversion among intravenous drug users in- and out-of-treatment: an 18-month prospective follow-up. J Acquir Immune Defic Syndr 1993; 6:1049-56.

13. Hirshfield S, Remien RH, Walavalkar I, Chiasson MA. Crystal methamphetamine use predicts incident STD infection among men who have sex with men recruited online: a nested case-control study. J Med Internet Res 2004; 6:e41.

14. Halkitis PN, Parsons JT, Stirratt MJ. A double epidemic: crystal methamphetamine drug use in relation to HIV transmission among gay men. J Homosex 2001; 41:17-35.

15. Halkitis PN, Parsons JT, Wilton L. Barebacking among gay and bisexual men in New York City: explanations for the emergence of intentional unsafe behavior. Arch Sex Behav 2003; 32:351-7.
16. Shoptaw S, Reback CJ, Freese TE. Patient characteristics, HIV serostatus, and risk behaviors among gay and bisexual males seeking treatment for methamphetamine abuse and dependence in Los Angeles. J Addict Dis 2002; 21:91-105.

17. Colfax G, Coates TJ, Husnik MJ, Huang Y, Buchbinder S, Koblin B, et al. Longitudinal patterns of methamphetamine, popper (amyl nitrite), and cocaine use and high-risk sexual behavior among a cohort of San Francisco men who have sex with men. J Urban Health 2005; 82 (1 Suppl 1):i62-70.

18. Morin SF, Vernon K, Harcourt JJ, Steward WT, Volk J, Riess TH, et al. Why HIV infections have increased among men who have sex with men and what to do about it: findings from California focus groups. AIDS Behav 2003; 7:353-62.

19. Kim AA, Kent CK, Klausner JD. Risk factors for rectal gonococcal infection amidst resurgence in HIV transmission. Sex Transm Dis 2003; 30:8137.

20. Mattison AM, Ross MW, Wolfson T, Franklin D; San Diego HIV Neurobehavioral Research Center Group. Circuit party attendance, club drug use, and unsafe sex in gay men. J Subst Abuse 2001; 13:119-26.

21. Semple SJ, Patterson TL, Grant I. A comparison of injection and non-injection methamphetamineusing HIV positive men who have sex with men. Drug Alcohol Depend 2004; 76:203-12.

22. Beyrer C, Razak MH, Jittiwutikarn J, Suriyanon V, Vongchak T, Srirak N, et al. Methamphetamine users in northern Thailand: changing demographics and risks for HIV and STD among treatmentseeking substance abusers. Int J STD AIDS 2004; 15:697-704.

23. Bautista CT, Sanchez JL, Montano SM, LagunaTorres VA, Lama JR, Sanchez JL, et al. Seroprevalence of and risk factors for HIV-1 infection among South American men who have sex with men. Sex Transm Infect 2004; 80:498-504.

24. Shoptaw S, Reback CJ, Frosch DL, Rawson RA. Stimulant abuse treatment as HIV prevention. J Addict Dis 1998; 17:19-32.

25. Reback CJ, Larkins S, Shoptaw S. Changes in the meaning of sexual risk behaviors among gay and bisexual male methamphetamine abusers before and after drug treatment. AIDS Behav 2004; 8:8798.

26. Klein A. "Have a piss, drink ogogoro, smoke igbo, but don't take gbana"- hard and soft drugs in Nigeria: a critical comparison of official policies and the view on the street. J Psychoactive Drugs 2001; 33:111-9.

27. Odek-Ogunde M, Pande-Leak D. Prevalence of substance use among students in a Kenyan University: a preliminary report. East Afr Med J 1999; 76:301-6.

28. Adesanya A, Ohaeri JU, Ogunlesi AO, Adamson TA, Odejide OA. Psychoactive substance abuse among inmates of a Nigerian prison population. Drug Alcohol Depend 1997; 47:39-44.

29. Booth RE, Watters JK. How effective are risk-reduction interventions targeting injecting drug users? AIDS 1994; 8:1515-24. 
30. Gibson DR, McCusker J, Chesney M. Effectiveness of psychosocial interventions in preventing HIV risk behaviour in injecting drug users. AIDS 1998; 12:919-29.

31. Bandura A. Social cognitive theory and exercise of control over HIV infection. In: DiClemente RJ, Peterson JL, editors. Preventing AIDS: theories and methods of behavioral interventions. AIDS revention and mental health. New York: Plenum Press; 1994. p. 5-59.

32. Latkin C, Mandell W, Vlahov D, Oziemkowska M, Celentano D. The long term outcome of a personal network-oriented HIV prevention intervention for injecting drug users: the SAFE Study. Am J Community Psychol 1996; 24:3-11.

33. Trotter II RT, Bowen AM, Potter Jr. JM. Network models for HIV outreach and prevention programs for drug users. NIDA Res Monogr 1995; 151:144-80.

34. Kelly JA, McAuliffe TL, Sikkema KJ, Murphy DA Somlai AM, Mulry G, et al. Reduction in risk behavior among adults with severe mental illness who learned to advocate for HIV prevention. Psychiatr Serv 1997; 48:1283-8.

35. Kelly JA. Popular opinion leaders and HIV prevention peer education: resolving discrepant findings, and implications for the development of effective community programmes. AIDS Care 2004; 16:139-50.

36. Abdala N, Crowe M, Tolstov Y, Heimer R. Survival of human immunodeficiency virus type 1 after rinsing injection syringes with different cleaning solutions. Subst Use Misuse 2004; 39:581-600.

37. Shapshak P, McCoy CB, Shah SM, Page JB, Rivers JE, Weatherby NL, et al. Preliminary laboratory studies of inactivation of HIV-1 in needles and syringes containing infected blood using undiluted household bleach. J Acquir Immune Defic Syndr 1994; 7:754-9.

38. Vlahov D, Astemborski J, Solomon L, Nelson KE. Field effectiveness of needle disinfection among injecting drug users. J Acquir Immune Defic Syndr 1994; 7:760-6.

39. Titus S, Marmor M, Des Jarlais D, Kim M, Wolfe H, Beatrice S. Bleach use and HIV seroconversion among New York City injection drug users. J Acquir Immune Defic Syndr 1994; 7:700-4.

40. Moss AR, Vranizan K, Gorter R, Bacchetti P, Watters J, Osmond D. HIV seroconversion in intravenous drug users in San Francisco, 1985-1990. AIDS 1994; 8:223-31.

41. National Institutes of Health. Interventions to prevent HIV risk behaviors. National Institutes of Health Consensus Development Conference Statement February 11-13, 1997. AIDS 2000; 14 Suppl 2:S85-96.

42. Des Jarlais DC. Structural interventions to reduce HIV transmission among injecting drug users. AIDS 2000; 14 Suppl 1:S41-6.

43. Kelly JA. Community-level interventions are needed to prevent new HIV infection. Am J Public Health 1999; 89:299-301.

44. Guenther-Grey C, Noroian D, Fonseka J, Higgins D. Developing community networks to deliver HIV prevention interventions. Public Health Rep 1996; 111 Suppl 1:41-9.
45. Williams LS. AIDS risk reduction: a community health education intervention for minority high risk group members. Health Educ Q 1986; 13:40721.

46. Sun X, Huang C, Wen Y. A community-based acquired immunodeficiency syndrome education intervention study in Kunshan county. Zhonghua Liu Xing Bing Xue Za Zhi 2001; 22:326-9.

47. Elkins D, Maticka-Tyndale E, Kuyyakanond T, Miller P, Haswell-Elkins M. Toward reducing the spread of HIV in northeastern Thai villages: evaluation of a village-based intervention. AIDS Educ Prev 1997; 9:49-69.

48. Barrett ME, de Palo MP. Community-based intervention to reduce demand for drugs in Northern Thai tribal villages. Subst Use Misuse 1999; 34 : 1837-79.

49. Hinton A, Downey J, Lisovicz N, Mayfield-Johnson S, White-Johnson F. The community health advisor program and the deep South network for cancer control: health promotion programs for volunteer community health advisors. Fam Community Health 2005; 28:20-7.

50. Garcia P, Hughes J, Carcamo C, Holmes KK. Training pharmacy workers in recognition, management, and prevention of STDs: district-randomized controlled trial. Bull World Health Organ 2003; 81:806-14.

51. Cheadle A, Wagner E, Walls M, Diehr P, Bell M, Anderman C, et al. The effect of neighborhoodbased community organizing: results from the Seattle Minority Youth Health Project. Health Serv Res 2001; 36:671-89.

52. Wagner EH, Wickizer TM, Cheadle A, Psaty BM, Koepsell TD, Diehr P, et al. The Kaiser Family Foundation Community Health Promotion Grants Program: findings from an outcome evaluation. Health Serv Res 2000; 35:561-89.

53. O'Loughlin J, Renaud L, Richard L, Gomez LS Paradis G. Correlates of the sustainability of community-based heart health promotion interventions. Prev Med 1998; 27 (5 Pt 1):702-12.

54. Darrow WW, Montanea JE, Fernandez PB, Zucker UF, Stephens DP, Gladwin H. Eliminating disparities in HIV disease: community mobilization to prevent HIV transmission among Black and Hispanic young adults in Broward County, Florida. Ethn Dis 2004; 14 (3 Suppl 1):S108-16.

55. Pentz MA, Dwyer JH, MacKinnon DP, Flay BR Hansen WB, Wang EY, et al. A multicommunity trial for primary prevention of adolescent drug abuse. Effects on drug use prevalence. JAMA 1989; 261:3259-66.

56. Wu Z, Detels R, Zhang J, Li V, Li J. Communitybased trial to prevent drug use among youths in Yunnan, China. Am J Public Health 2002; 92:19527.

57. Groseclose SL, Weinstein B, Jones TS, Valleroy LA, Fehrs LJ, Kassler WJ. Impact of increased legal access to needles and syringes on practices of injecting-drug users and police officers - Connecticut, 1992-1993. J Acquir Immune Defic Syndr Hum Retrovirol 1995; 10:82-9.

58. Diaz T, Chu SY, Weinstein B, Mokotoff E, Jones TS. Injection and syringe sharing among HIV-infected injection drug users: implications for preven- 
tion of HIV transmission. Supplement to HIV/AIDS Surveillance Group. J Acquir Immune Defic Syndr Hum Retrovirol 1998; 18 Suppl 1:S76-81.

59. Wang DB, Zhang XJ, Zhang HB, Zhang CY, Su B. A rapid assessment of community-wide HIV/STI intervention in China. Sex Transm Infect 2005; 81:47-52.

60. Hu DJ, Vanichseni S, Mock PA, Young NL, Dobbs T, Byers Jr. RH, et al. HIV type 1 incidence estimates by detection of recent infection from a cross-sectional sampling of injection drug users in Bangkok: use of the IgG capture BED enzyme immunoassay. AIDS Res Hum Retroviruses 2003; 19:727-30.

61. Strathdee SA, Galai N, Safaiean M, Celentano DD, Vlahov D, Johnson L, et al. Sex differences in risk factors for HIV seroconversion among injection drug users: a 10-year perspective. Arch Intern Med 2001; 161:1281-8.

62. Longshore D, Annon J, Anglin MD. Long-term trends in self-reported HIV risk behavior: injection drug users in Los Angeles, 1987 through 1995. J Acquir Immune Defic Syndr Hum Retrovirol 1998; 18:64-72.

63. Maslow CB, Friedman SR, Perlis TE, Rockwell R, Des Jarlais DC. Changes in HIV seroprevalence and related behaviors among male injection drug users who do and do not have sex with men: New York City, 1990-1999. Am J Public Health 2002; 92:382-4.

64. National Institute on Drug Abuse/World Health Organization. Report on street children and drug abuse: social and health consequences. Bethesda: National Institute on Drug Abuse/World Health Organization; 2000.

65. Hammer SM, Squires KE, Hughes MD, Grimes JM, Demeter LM, Currier JS, et al. A controlled trial of two nucleoside analogues plus indinavir in persons with human immunodeficiency virus infection and CD4 cell counts of 200 per cubic millimeter or less. AIDS Clinical Trials Group 320 Study Team. N Engl J Med 1997; 337:725-33.

66. Detels R, Munoz A, McFarlane G, Kingsley LA, Margolik JB, Schrager LK, et al. Effectiveness of potent antiretroviral therapy on time to AIDS and death in men with known HIV infection duration. Multicenter AIDS Cohort Study Investigators. JAMA 1998; 280:1497-503.

67. The CASCADE Collaboration. Survival after introduction of HAART in people with known duration of HIV-1 infection. Lancet 2000; 355:1158-9.

68. Murphy EL, Collier AC, Kalish LA, Assmann SF, Para MF, Flanigan TP, et al. Highly active antiretroviral therapy decreases mortality and morbidity in patients with advanced HIV disease. Ann Intern Med 2001; 135:17-26.

69. Anastos K, Barron Y, Miotti P, Weiser B, Young M, Hessol N, et al. Risk of progression to AIDS and death in women infected with HIV-1 initiating highly active antiretroviral treatment at different stages of disease. Arch Intern Med 2002; 162:197380.

70. Hogg RS, Yip B, Chan KJ, Wood E, Craib KJ, O'Shaughnessy MV, et al. Rates of disease progression by baseline CD4 cell count and viral load after initiating triple-drug therapy. JAMA 2001; 286:2568-77.
71. Egger M, May M, Chene G, Phillips AN, Lederberger B, Dabis F, et al. Prognosis of HIV-1-infected patients starting highly active antiretroviral therapy: a collaborative analysis of prospective studies. Lancet 2002; 360:119-29.

72. Galai N, Vlahov D, Margolick JB, Chen K, Graham NM, Munoz A. Changes in markers of disease progression in HIV-1 seroconverters: a comparison between cohorts of injecting drug users and homosexual men. J Acquir Immune Defic Syndr Hum Retrovirol 1995; 8:66-74.

73. Pezzotti P, Galai N, Munoz A, Vlahov D, Rezza G. Declino dei linfociti CD4+ dopo la sieroconversione: uno studio longitudinale su 941 soggetti. Giornale Italiano dell'AIDS 1994; 5:93-100.

74. Pezzotti P, Galai N, Vlahov D, Rezza G, Lyles CM, Astemborski J. Direct comparison of time to AIDS and infectious disease death between HIV seroconverter injection drug users in Italy and the United States: results from the ALIVE and ISS studies. AIDS Link to Intravenous Experiences. Italian Seroconversion Study. J Acquir Immune Defic Syndr Hum Retrovirol 1999; 20:275-82.

75. Junghans C, Low N, Chan P, Witschi A, Vernazza P, Egger M. Uniform risk of clinical progression despite differences in utilization of highly active antiretroviral therapy: Swiss HIV Cohort Study. AIDS $1999 ; 13: 2547-54$.

76. Mocroft A, Madge S, Johnson AM, Lazzarin A, Clumeck N, Goebel FD, et al. A comparison of exposure groups in the EuroSIDA study: starting highly active antiretroviral therapy (HAART), response to HAART, and survival. J Acquir Immune Defic Syndr 1999; 22:369-78.

77. Vlahov D, Galai N, Safaeian M, Galea S, Kirk GD, Lucas GM, Sterling TR. Effectiveness of highly active antiretroviral therapy among injection drug users with late-stage human immunodeficiency virus infection. Am J Epidemiol 2005; 161:9991012.

78. Wang C, Vlahov D, Galai N, Bareta J, Strathdee SA, Nelson KE, et al. Mortality in HIV-seropositive versus -seronegative persons in the era of highly active antiretroviral therapy: implications for when to initiate therapy. J Infect Dis 2004; 190: 1046-54.

79. Lucas GM, Cheever LW, Chaisson RE, Moore RD. Detrimental effects of continued illicit drug use on the treatment of HIV-1 infection. J Acquir Immune Defic Syndr 2001; 27:251-9.

80. Poundstone KE, Chaisson RE, Moore RD. Differences in HIV disease progression by injection drug use and by sex in the era of highly active antiretroviral therapy. AIDS 2001; 15:1115-23.

81. Celentano DD, Galai N, Sethi AK, Shah NG, Strathdee SA, Vlahov D, et al. Time to initiating highly active antiretroviral therapy among HIVinfected injection drug users. AIDS 2001; 15:170715.

82. Wood E, Montaner JS, Yip B, Tyndall MW, Schechter MT, O'Shaughnessy MV, et al. Adherence and plasma HIV RNA responses to highly active antiretroviral therapy among HIV-1 infected injection drug users. CMAJ 2003; 169:656-61.

83. Carpenter CCJ, Fischl MA, Hammer SM, Hirsch MS, Jacobsen DM, Katzenstein DA, et al. Anti- 
retroviral therapy for HIV infection in 1997: updated recommendations of the International AIDS Society- USA panel. JAMA 1997; 277:1962-9.

84. Strathdee SA, Palepu A, Corneliesse PG, Yip B, O'Shaughnessy MV, Montaner JS, et al. Barriers to use of free antiretroviral therapy in injection drug users. JAMA 1998; 280:547-9.

85. Celentano DD, Vlahov D, Cohn S, Shadle VM, Obasanjo O, Moore RD. Self-reported antiretroviral therapy in injection drug users. JAMA 1999; 280:544-6.

86. Shapiro MF, Morton SC, McCaffrey DF, Senterfitt JW, Fleishman JA, Perlman JF, et al. Variations in the care of HIV-infected adults in the United States. Results from the HIV Cost and Services Utilization Study. JAMA 1999; 281:2305-15.

87. Bozette SA, Berry SH, Duan N, Frankel MR, Leibowitz AA, Emmons CA, et al. The care of HIV-infected adults in the United States. N Engl J Med 1998; 339:1897-904.

88. Dorucci M, Pezzotti P, Phillips AN, Alliegro MB, Rezza G. Antiretroviral treatment and progression to AIDS in HIV seroconverters from different risk groups. AIDS 1997; 11:461-7.

89. Stein MD, Piette J, Mor V, Wachtel TJ, Fleishman J, Mayer KH, et al. Differences in access to zidovudine (AZT) among symptomatic HIV-infected persons. J Gen Intern Med 1991; 6:35-40.

90. Roseberg PS, Gail MH, Schrager LK, Vermund SH, Creagh-Kirk T, Andrews EB, et al. National AIDS incidence trends and the extent of zidovudine therapy in selected demographic and transmission groups. J Acquir Immune Defic Syndr Hum Retrovirol 1991; 4:392-401.

91. McKinney MM, Marconi KM. Delivering HIV services to vulnerable populations: a review of CARE Act-funded research. Public Health Rep 2002; 117:99-113

92. Solomon L, Frank R, Vlahov D, Astemborski J. Utilization of health services in a cohort of intravenous drug users with known HIV-1 serostatus. Am J Public Health 1991; 81:1285-9.

93. Dykeman MC, Sternberg C, Jasek J, McGee DS, Driscoll M, Cohen V, et al. A model for the delivery of care for HIV-positive clients. AIDS Patient Care STDS 1996; 10:240-5.

94. Brosgart CL, Mitchell TF, Coleman RL, Dyner T, Stephenson KE, Abrams DI. Clinical experience and choice of drug therapy for human immunodeficiency virus disease. Clin Infect Dis 1996; 28:14-25.

95. Paauw DS, Wenrich MD, Curtis JR, Carline JD, Ramsey PG. Ability of primary care physicians to recognize physical findings associated with HIV infection. JAMA 1995; 274:1380-2.

96. Bangsberg D, Tulsky JP, Hecht FM, Moss AR. Protease inhibitors in the homeless. JAMA 1997; 278:63-5.

97. Imrie A, Beveridge A, Genn W, Vizzard J, Cooper DA; The Sydney Primary HIV Infection Study Group. Transmission of human immunodeficiency virus type 1 resistant to nevirapine and zidovudine. J Infect Dis 1997; 175:1502-6.

98. Hecht FM, Grant RM, Petropoulos CJ, Dillon B, Chesney MA, Tian H, et al. Sexual transmission of an HIV-1 variant resistant to multiple reverse- transcriptase and protease inhibitors. N Engl J Med 1998; 339:307-11.

99. Gallant JE. Strategies for long-term success in the treatment of HIV infection. JAMA 2000; 283:132934.

100. Bangsberg D, Tulsky JP, Hecht FM, Moss AR. Protease inhibitors in the homeless. JAMA 1997; 278:63-5.

101. Altice FL, Friedland GH. The era of adherence to HIV therapy. Ann Intern Med 1998; 129:504-5.

102. Panel on Clinical Practices for Treatment of HIV Infection/U.S. Department of Health and Human Services/Henry J. Kaiser Family Foundation. Guidelines for the Use of Antiretroviral Agents in HIV-Infected Adults and Adolescents. MMWR Recomm Rep 1998; 47 (RR-4):1-43.

103. Paterson DL, Swindells S, Mohr J, Brester M, Vergis EM, Squier C, et al. Adherence to protease inhibitor therapy and outcomes in patients with HIV infection. Ann Intern Med 2000; 136:21-30.

104. Wainberg MA, Friedland G. Public health implication of antiretroviral therapy and HIV drug resistance. JAMA 1998; 279:1977-83.

105. Friedland GH, Williams A. Attaining higher goals in HIV treatment: the central importance of adherence. AIDS 1999; 13 Suppl 1:S61-72.

106. Golin CE, Liu H, Hays RD, Miller LG, Beck CK, Ickovicks J, et al. A prospective study of predictors of adherence to combination antiretroviral medication. J Gen Intern Med 2002; 17:756-65.

107. Haubrich RH, Little SJ, Currier JS, Forthal DN, Kemper CA, Beall GN, et al. The value of patientreported adherence to antiretroviral therapy in predicting virologic and immunologic response. AIDS 1999, 13:1099-107.

108. Gifford AL, Bormann JE, Shively MJ, Wright BC, Richman DD, Bozzette SA. Predictors of self-reported adherence and plasma HIV concentrations in patients on multidrug antiretroviral regimens. J Acquir Immune Defic Syndr 2000; 23:386-95.

109. Lucas GM, Cheever LW, Chaisson RE, Moore RD. Detrimental effects of continued illicit drug use on the treatment of HIV-1 infection. J Acquir Immune Defic Syndr 2001; 27:251-9.

110. Singh N, Berman SM, Swindells S, Justis JC, Mohr JA, Squier C, et al. Adherence of HIV-infected patients to antiretroviral therapy. Clin Infect Dis 1999; 29:824-30.

111. Lin MK, Sethi A, Wu W, Strathdee SA, Celentano DD, Vlahov D. Adherence to HAART, HIV-1 RNA level, and genotypic resistance among injection drug users in Baltimore, Maryland. In: XIV International AIDS Conference. Barcelona: International AIDS Society; 2002.

112. Arnsten JH, Demas PA, Grant RW, Gourevitch MN, Farzadegan H, Howard AA, et al. Impact of active drug use on antiretroviral therapy adherence and viral suppression in HIV-infected drug users. J Gen Intern Med 2002; 17:377-81.

113. Sambamoorthi U, Warner LA, Crystal S, Walkup J. Drug abuse, methadone treatment, and health services use among injection drug users with AIDS. Drug Alcohol Depend 2000; 60:77-89.

114. Turner BJ. Adherence to antiretroviral therapy by Human Immunodeficiency Virus-infected patients. J Infect Dis 2002; 185 Suppl 2:S143-51. 
115. Hubbard RL, Marsden ME, Cavanaugh E, Rachal JV, Ginzburg HM. Role of drug abuse treatment in limiting the spread of AIDS. Rev Infect Dis 1988; 10:377-84.

116. Metzger DS, Woody GE, McLellan AT, O’Brien CP, Druley P, Navaline H, et al. HIV seroconversion among intravenous drug users in- and out-oftreatment: an 18-month prospective follow-up. J Acquir Immune Defic Syndr 1993; 6:1049-56.

117. Ball JC, Ross A. The effectiveness of methadone maintenance treatment. New York: Springer Verlag; 1991.

118. Sorensen J, Copeland A. Substance abuse treatment as an HIV prevention strategy: a review. Drug Alcohol Depend 2000; 59:17-31.

119. Johnson MO, Catz SL, Remien RH, RotheramBorus MJ, Morin SF, Charlebois E, et al. Theoryguided, empirically supported avenues for intervention on HIV medication non-adherence: findings from the Health Living Project. AIDS Patient Care STDS 2003; 17:645-56.

120. Kleeberger CA, Phair JP, Strathdee SA, Detels R, Kingsley K, Jacobson LP. Determinants of heterogeneous adherence to HIV-antiretroviral therapies in the Multicenter AIDS Conhort Study. J Acquir Immune Defic Syndr 2001; 26:82-92.

121. Cheever LW, Wu AW. Medication adherence among HIV-infected patients: understanding the complex behavior of patients taking this complex therapy. Curr Infect Dis Rep 1999; 1:401-7.

122. Fogarty L, Roter D, Larson S, Burke J, Gillespie J, Levy R. Patient adherence to HIV medication regimens: a review of published and abstract reports. Patient Educ Couns 2002; 46:93-108.

123. Bartlett JA. Addressing the challenges of adherence. J Acquir Immune Defic Syndr 2002; 29:S2-10.

124. Katz MH, Schwarcz SK, Kellogg TA, Klausner JD, Dilley JW, Gibson S, et al. Impact of highly active antiretroviral treatment on HIV seroincidence among men who have sex with men: San Francisco. Am J Public Health 2002; 92:388-94.

125. Centers for Disease Control and Prevention. Increases in unsafe sex and rectal gonorrhea among men who have sex with men - San Francisco, California, 1994-1997. MMWR Morb Mortal Wkly Rep 1999; 48:45-8.

126. Dukers NH, Goudsmit J, de Wit JB, Prins M, Weverling GJ, Coutinho RA. Sexual risk behaviour relates to the virological and immunological improvements during highly active antiretroviral therapy in HIV-1 infection. AIDS 2001; 15: 369-78.

127. Kalichman SC, Rompa D, Austin J, Luke W, DiFonzo K. Viral load, perceived infectivity, and unprotected intercourse. J Acquir Immune Defic Syndr 2001; 28:303-5.

128. Kelly JA, Hoffman RG, Rompa D, Gray M. Protease inhibitor combination therapies and perceptions of gay men regarding AIDS severity and the need to maintain safer sex. AIDS 1998; 12:F915.

129. Herlitz CA, Steel JL. Highly active antiretroviral therapy (HAART). Awareness and beliefs about infectivity and the influence on sexual behaviour in the general population of Sweden. Eur J Public Health 2001; 11:251-6.
130. Miller M, Meyer L, Boufassa F, Persoz A, Sarr A, Robain M, et al. Sexual behavior changes and protease inhibitor therapy. SEROCO Study Group. AIDS 2000; 14:F33-9.

131. Ostrow DG, Fox K, Chmiel JS, Silvestre A, Visscher BR, Vanable PA, et al. Attitudes towards highly active antiretroviral therapy are associated with sexual risk taking among HIV-infected and uninfected homosexual men. AIDS 2002; 16:775-80.

132. DiClemente RJ, Funkhouser E, Wingood G, Fawal H, Holmberg SD, Vermund SH. Protease inhibitor combination therapy and decreased condom use among gay men. South Med J 2002; 95:421-5.

133. Bouhnik AD, Moatti JP, Vlahov D, Gallais H, Dellamonica P, Obadia Y. Highly active antiretroviral treatment does not increase sexual risk behaviour among French HIV infected injecting drug users. J Epidemiol Community Health 2002; 56:349-53.

134. Vlahov D, Safaien M, Lai S, Strathdee SA, Johnson L, Sterling T, et al. Sexual and drug risk-related behaviours after initiating highly active antiretroviral therapy among injection drug users. AIDS 2001; 15:2311-6.

135. Tun W, Gange SJ, Vlahov D, Strathdee SA, Celentano DD. Increase in sexual risk behavior associated with immunologic response to highly active antiretroviral therapy among HIV-infected injection drug users. Clin Infect Dis 2004; 38:1167-74.

136. Tun W, Celentano DD, Vlahov D, Strathdee SA. Attitudes toward HIV treatments influence unsafe sexual and injection practices among injecting drug users. AIDS 2003; 17:1953-62.

137. Crepaz N, Hart TA, Marks G. Highly active antiretroviral therapy and sexual risk behavior: a meta-analytic review. JAMA 2004; 292:224-36.

138. Little SJ, Holte S, Routy JP, Daar ES, Markowitz M, Collier AC, et al. Antiretroviral-drug resistance among patients recently infected with HIV. N Engl J Med 2002; 347:385-94.

139. Markowitz M, Mohri H, Mehandru S, Shet A, Berry L, Kalyanaraman R, et al. Infection with multidrug resistant, dual-tropic HIV-1 and rapid progression to AIDS: a case report. Lancet 2005; 365:1031-8.

140. Alexander CS, Dong W, Schechter MT, O'Shaughnessy MV, Strathdee SA, Mo T, et al. Prevalence of primary HIV drug resistance among seroconverters during an explosive outbreak of HIV infection among injecting drug users. AIDS 1999; 13:981-5.

141. Boden D, Hurley A, Zhang L, Cao Y, Guo Y, Jones E, et al. HIV-1 drug resistance in newly infected individuals. JAMA 1999; 282:1135-41.

142. Little SJ, Daar ES, D’Aquila RT, Keiser PH, Connick E, Whitcomb JM, et al. Reduced antiretroviral drug susceptibility among patients with primary HIV infection. JAMA 1999; 282:1142-9.

143. Salomon H, Wainberg MA, Brenner B, Quan Y, Rouleau D, Cote P, et al. Prevalence of HIV-1 resistant to antiretroviral drugs in 81 individuals newly infected by sexual contact or injecting drug use. Investigators of the Quebec Primary Infection Study. AIDS 2000; 14:F17-23.

144. Weinstock H, Respess R, Heneine W, Petropoulos CJ, Hellmann NS, Luo CC, et al. Prevalence of mutations associated with reduced antiretroviral drug susceptibility among Human Immunodefi- 
ciency Virus type 1 seroconverters in the United States, 1993-1998. J Infect Dis 2000; 182:330-3.

145. Briones C, Perez-Olmeda M, Rodriguez C, del Romero J, Hertogs K, Soriano V. Primary genotypic and phenotypic HIV-1 drug resistance in recent seroconverters in Madrid. J Acquir Immune Defic Syndr 2001; 26:145-50.

146. Duwe S, Brunn M, Altmann D, Hamouda O, Schmidt B, Walter H, et al. Frequency of genotypic and phenotypic drug-resistant HIV-1 among therapy-naive patients of the German Seroconverter Study. J Acquir Immune Defic Syndr 2001; 26:266-73.

147. UK Collaborative Group on Monitoring the Transmission of HIV Drug Resistance. Analysis of prevalence of HIV-1 drug resistance in primary infections in the United Kingdom. BMJ 2001; 322:1087-8.
148. Harzic M, Pellegrin I, Deveau C, Chaix ML, Dubeaux B, Garrigue I, et al. Genotypic drug resistance during HIV-1 primary infection in France (1996-1999): frequency and response to treatment. AIDS 2002; 16:793-6.

149. Grant RM, Hecht FM, Warmerdam M, Liu L, Liegler T, Petropoulos CJ, et al. Time trends in primary HIV-1 drug resistance among recently infected persons. JAMA 2002; 288:181-8.

150. Sethi AK, Celentano DD, Gange SJ, Gallant JE, Vlahov D, Farzadegan H. High-risk behavior and potential transmission of drug-resistant HIV among injection drug users. J Acquir Immune Defic Syndr 2004; 35:503-10.

Submitted on $4 / \mathrm{Jul} / 2005$ Approved on 28/Jul/2005 